\title{
IMPACT OF A $20 \%$ BIODIESEL IN DIESEL BLEND ( B20 ) ON VEHICLES
}

\author{
Márcia Figueiredo Moreira ${ }^{1}$ and Décio Magioli Maia ${ }^{1}$ \\ ${ }^{1}$ Petrobras \\ E-mails: marciafigueiredo@petrobras.com.br, deciomaia@petrobras.com.br
}

\begin{abstract}
The use of biodiesel in Brazil was consolidated after 2005, when the Federal Government established a time frame to insert biodiesel in Brazilian energy matrix and so that a $5 \%$ biodiesel in diesel blend (B5) has been mandatory since January, 2010. Now the attention turns to blends with higher level of biodiesel and vehicle and engine assemblers, fleet owners and other private and governmental entities are conducting extensive researches on the subject.
\end{abstract}

This paper evaluates the use of a $20 \%$ biodiesel in diesel blend (B20) in light duty vehicles with EURO III and EURO IV technologies and its impact on the durability of engines and systems. Vehicles of both technologies endured a field test during which they accumulated $100.000 \mathrm{~km}$ in urban and road circuits. They were then evaluated according to the deterioration of performance and pollutants emissions and wear of parts and components. Results were compared to those obtained in similar vehicles using a B5 blend as fuel, subjected to the same test conditions.

Engine wear and deposit formation on rings, pistons and cylinders were evaluated by the manufacturers through visual and dimensional inspections, and were found compatible to the use of the engines; there was no significant differences between the groups. Track performance and chassis dynamometer emissions tests showed that EURO IV vehicles were less influenced by the use of differentiated fuels, with vehicles that run on B20 during the field test showing results statistically equivalent to those that run on B5. On the other hand, EURO III vehicles that run on B20 had performance losses up to 7\% when compared to those that run on B5. They could not be evaluated according to their emissions.

\section{INTRODUCTION}

Fuels of vegetal origin have been used in diesel engines since the dawn of its history. The most famous and quoted example is provided by Rudolph Diesel himself, who used peanut oil as fuel for his engine during its presentation in Paris World Fair, in 1900. And since then there also have been reports on problems associated to its use, such as excessive deposit formation on injectors, valves and combustion chambers [1].

Biodiesel as defined today - a vegetable oil- or animal fat-based diesel fuel consisting of long-chain alkyl esters [2] - was firstly proposed as a response to some of those problems. Now, more than 75 years after the first patent of biodiesel was deposited in Belgium, it plays an important part on world's fuels scenario. 
In Brazil, use of biodiesel was made official in 2005, when the Federal Government published Law 11.097 establishing a schedule to insert mandatory contents of biodiesel in diesel. At the same time, it created an official program [3] to enhance the production and the use of biodiesel that included series of tests in engines and vehicles to validate its technical feasibility. Those tests made possible to anticipate the proposed schedule in three years, and the adoption of a 5\% blend (B5) was made nationwide obligatory since January ${ }^{\text {st }}, 2010$.

The challenge now is to gather information on the performance of higher blends of biodiesel in diesel. Manufacturers of engines, vehicles and injection systems, fleet owners and other governmental and private entities are conducting tests on this subject. This work is part of that initiative, and evaluates the use of a $20 \%$ biodiesel in diesel blend on light vehicles with EURO III and EURO IV and its impact on the durability of its engines and systems.

\section{TEST VEHICLES}

Eight vehicles were used: four Ford Rangers XLT 13P and four Ford Transits 330C TM. Table 1 presents their specifications.

Table 1. Vehicles technical specifications

\begin{tabular}{|c|c|c|c|}
\hline & & Ford Ranger & Ford Transit \\
\hline \multirow{7}{*}{ 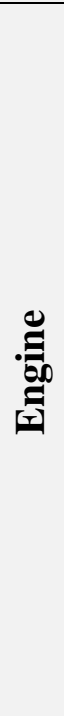 } & Manufacturer & MWM International & Ford \\
\hline & Model & $\begin{array}{l}\text { Diesel Power Stroke 3.0L } \\
\text { Electronic }\end{array}$ & Ford Duratorq $2.4 \mathrm{TDCi}$ \\
\hline & Type & \multicolumn{2}{|c|}{ Eletronic, turbodiesel } \\
\hline & Emissions Class & PROCONVE P5 & $\begin{array}{l}\text { PROCONVE LA } \\
\text { (EURO 4, in Europe) }\end{array}$ \\
\hline & Injection System & \multicolumn{2}{|c|}{ Common rail } \\
\hline & Maximum Power & 120 kW@3500 rpm & 85 kW @ 3500 rpm \\
\hline & Maximum Torque & $360 \mathrm{Nm} @ 1800-2400 \mathrm{rpm}$ & 310 Nm @ 1750-2000 rpm \\
\hline \multirow{2}{*}{ } & $\begin{array}{l}\text { Total Gross } \\
\text { Weight (TGW) }\end{array}$ & $3057 \mathrm{~kg}$ & $3350 \mathrm{~kg}$ \\
\hline & $\begin{array}{l}\text { Maximum Speed } \\
\text { in TGW }\end{array}$ & $170 \mathrm{~km} / \mathrm{h}$ & $133 \mathrm{~km} / \mathrm{h}$ \\
\hline
\end{tabular}

The Ford Ranger is equipped with an MWM International Diesel Power Stroke 3.0L Electronic engine, turbocharged and with common rail injection system. It was certified as PROCONVE P5 according to Brazilian emissions legislation - which is equivalent to EURO III. 
The Ford Transit is equipped with a Ford Duratorq $2.4 \mathrm{TDCi}$, turbocharged engine with common rail injection system. It was produced in England and certified there as compliant to EURO IV emissions limits. In Brazil, it was certified as PROCONVE L4. Table 2 shows the emissions limits for those vehicles, according to legislation.

Table 2. Emission limits

\begin{tabular}{l|c|c|c|c|c|c|c}
\cline { 3 - 7 } \multicolumn{2}{c|}{} & NOx & CO & HC & $\begin{array}{c}\text { HC + } \\
\text { NOx }\end{array}$ & $\begin{array}{c}\text { NMH } \\
\text { C }\end{array}$ & PM \\
\hline PROCONVE P5 & g/kW h & 5,0 & 2,1 & 0,66 & -- & -- & 0,10 \\
\hline EURO 4 & g/km & 0,39 & 0,74 & -- & 0,46 & -- & 0,06 \\
\hline PROCONVE L4 & g/km & 1,00 & 2,7 & -- & -- & 0,2 & 0,10 \\
\hline
\end{tabular}

In order to minimize the influence of performance deviations inherent to vehicle production on fuel comparison, it was established that those vehicles with the best and the worst performances - as verified before the field test - would use the reference fuel (B5), while those with intermediate behavior would run on B20, so that the results obtained with the reference fuel would be the limits for what would be considered accepted behavior.

It was also established that two vehicles of the same model running on the same fuel would be viewed as a single sample group. Table 3 shows the formation and identification of vehicles and groups during the tests.

Table 3. Vehicle identification

\begin{tabular}{|c|c|c|c|}
\hline \multirow[b]{2}{*}{ Vehicle } & \multicolumn{2}{|c|}{ Identification } & \multirow{2}{*}{$\begin{array}{c}\text { Field Test } \\
\text { Fuel }\end{array}$} \\
\hline & Field Test & $\begin{array}{c}\text { Sample } \\
\text { Group }\end{array}$ & \\
\hline \multirow{4}{*}{ 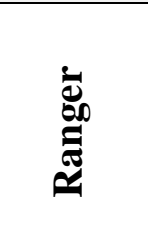 } & R1B5 & \multirow{2}{*}{ RB5 } & \multirow{2}{*}{ B5 } \\
\hline & R2B5 & & \\
\hline & R3B20 & \multirow{2}{*}{ RB20 } & \multirow{2}{*}{ B20 } \\
\hline & R4B20 & & \\
\hline \multirow{4}{*}{ 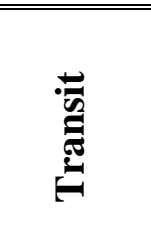 } & T1B5 & \multirow{2}{*}{ TB5 } & \multirow{2}{*}{ B5 } \\
\hline & T2B5 & & \\
\hline & T3B20 & \multirow{2}{*}{ TB20 } & \multirow{2}{*}{ B20 } \\
\hline & T4B20 & & \\
\hline
\end{tabular}

\section{FIELD TEST PROCEDURE}

For the field test, two groups of vehicles were formed, each one with four vehicles of the same model: two of them running on a reference fuel - a 5\% commercial blend of biodiesel in diesel (B5) - and the others running on a 20\% blend (B20). All vehicles of the same group traveled together, in caravan-style formation. A rotation of the vehicles position in the 
formation and of the drivers of each vehicle was made in order to prevent any influence of those variables in the results.

The test was conducted in urban circuits between the cities of Salvador and Lauro de Freitas (Bahia, Brazil) and road circuits that include the cities of Salvador, Feira de Santana, Ilhéus, Jequié, Itabuna, Seabra (Bahia, Brazil) and Monte Verde (Minas Gerais, Brazil). Each vehicle accumulated $100.000 \mathrm{~km}$ during one year.

\subsection{Fuel Economy}

Fuel consumption was measured for each vehicle in every refueling during the field test. Results shown in Figures 1 and 2 are the mean values obtained, respectively, for the Ford Rangers and the Ford Transits.

Figure 1. Fuel Economy for the Ford Rangers, according to running circuit
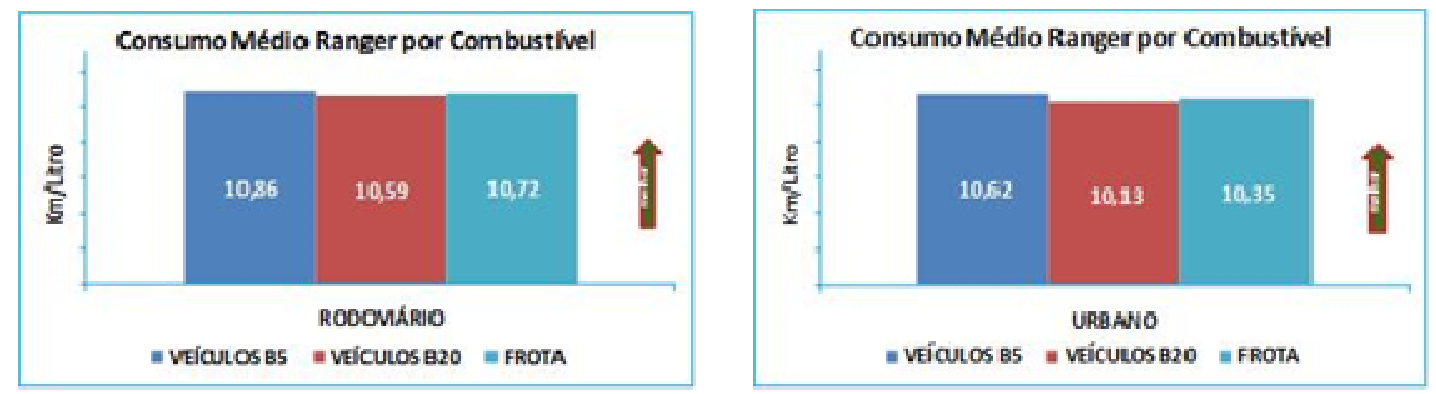

Figure 2. Fuel Economy for the Ford Transits, according to running circuit
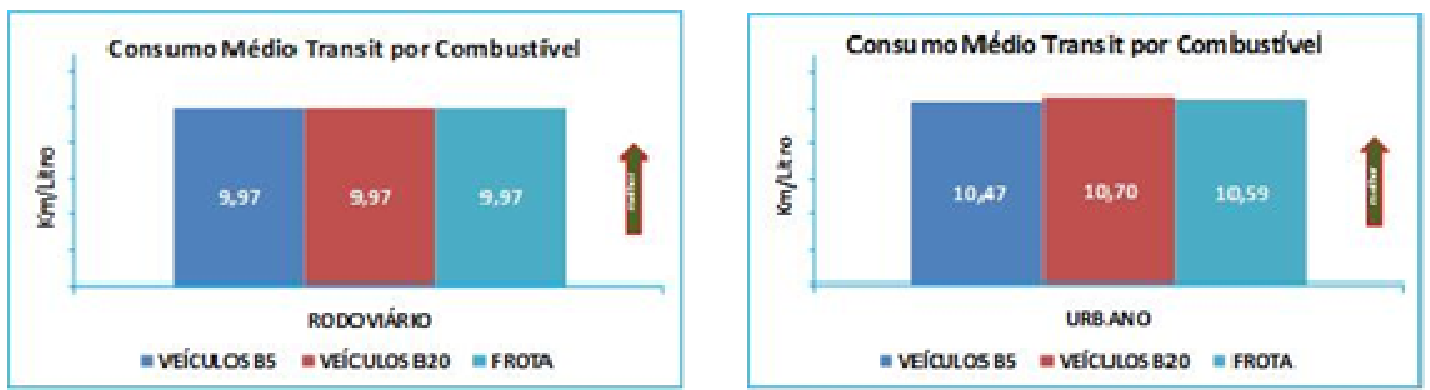

Among the Ford Rangers, fuel consumption was lower when using B5. The difference between B20 and B5 was up to 2,5\% in road circuits and to 4,6\% in urban circuits. For the Ford Transits, however, there was no significant difference between vehicles on B5 and on B20 in road circuits. In urban circuits, the difference was favorable to B20, and was up to $2,2 \%$. Design and powertrain adjustments are some of the possible causes for this behavior.

\subsection{Lubricant oil deterioration and contamination}

Both models of vehicles used lubricants specified by the manufacturer. The Ford Rangers used a mineral lubricant grade SAE 15W/40 (LUBRAX TOP TURBO) and the Ford Transits used a synthetic lubricant grade SAE 5W/30 (LUBRAX VALORA). Samples of the lubricants were taken periodically during the field test 
and were analyzed to verify their physical-chemical properties, wear metal and fuel contamination levels.

All properties observed were compatible with the applications and were compliant to the limits accepted by the producer of the lubricant and the manufacturer of the vehicles. There was no significant difference on the behavior of vehicles with different fuels.

\section{COLD START AND OPACITY}

Still during the field test, the vehicles were submitted to cold start tests on Monte Verde (MG). They were conditioned for 10 hours in temperatures from $-1^{\circ} \mathrm{C}$ to $2^{\circ} \mathrm{C}$ and then had their time till start and white smoke emission observed. For both models of vehicles, there was no significant difference in behavior between those with different fuels.

Opacity tests according to CONAMA Resolution n. 418, 2009 [4], were run every $20.000 \mathrm{~km}$. Again no significant difference between vehicles was observed.

\section{VEHICLE PERFORMANCE}

Vehicle performance was evaluated through acceleration tests. The procedure is based on SAE Recommended Practice J1491 [5] and measures the time necessary for the vehicle to go from one indicated speed to another, in maximum acceleration. The transmission gear is also specified in the procedure. The result of the test for each speed range is obtained by calculating the mean value of the times from consecutive runs made in opposite directions of the test lane, in order to minimize the influence of the wind and of some minor lane inclination.

Results for the Ford Rangers showed they were more influenciable by the content of biodiesel in the fuel. Those that run on B20 had performance losses up to 7\% when compared to those on B5. For the Ford Transits there was no significant difference, except in 60-100 km/h speed range as can be seen in Figure 3, below.

Figure 3. Performance diferences among groups of vehicles

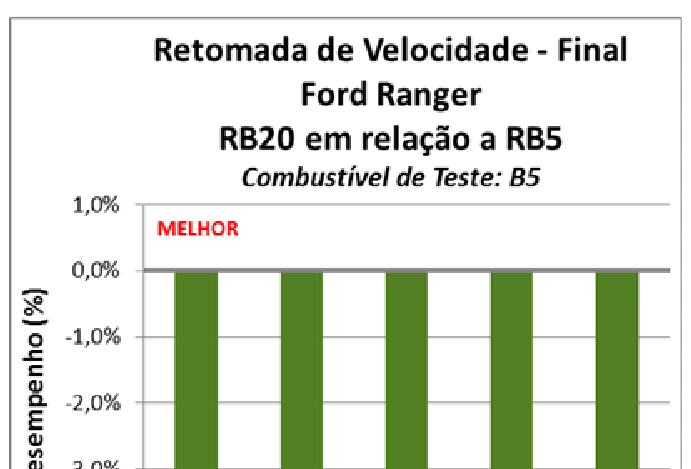




\section{TAILPIPE EMISSIONS}

Gaseous and particulate matter emissions in vehicles were evaluated according to Brazilian standard ABNT NBR 6601 [6]. During the test, exhaust gas samples were collected and afterwards analyzed to determine the emissions of carbon monoxide and dioxide (CO and $\mathrm{CO} 2$ ), total and non-methane hydrocarbons (THC and NMHC), nitrogen oxides (NOx) and particulate matter (PM). The results are presented in $\mathrm{g} / \mathrm{km}$.

Aldehydes emissions - which are not legislated for diesel vehicles in Brazil - were also measured. According to the procedure indicated in standard ABNT NBR 12026 [7], gas samples collected during the test were analyzed through high performance liquid chromatography, using DNPH (2,4 dinitrophenylhydrazine) method, and aldehydes and ketones emissions were determined.

Again the Ford Transits were less susceptible to the influence of the fuel. Vehicles that run on B20 during field test had results statistically equivalent to those that run on B5, indicating the same degree of emissions deterioration. The Ford Rangers had mechanical problems during the emissions tests, non-related to fuel properties, and could not be tested.

\section{ENGINE AND SYSTEMS WEAR}

\subsection{Engine mechanical wear}

After the end of the tests, the engines were disassembled and fully analyzed. Cylinder heads and blocks, cylinders, camshafts and crankshafts, inlet and exhaust valves and other moving parts were inspected for signs of excessive wear and corrosion. The Ford Rangers were analyzed by MWM International, in São Paulo (SP), and the Ford Transits were sent to Ford in England.

For the Ford Transits, there were no significant differences between the groups of vehicles and the wear of the parts was considered compatible with their use. There was no excessive formation of soot deposits on rings, pistons and cylinders, either.

The Ford Rangers that run on B20 showed more signs of wear than those that run on B5, specially on cylinder walls. There was no difference concerning deposit formation and wear on other parts of the engines.

6.2. Elastomers deterioration - refueling and fuel tank ventilation hoses

Elongation values observed during elastomers traction tests were used to evaluate elastomers degradation and were analyzed according to ASTM procedure D412:06ae2 (Die C) [8] at $23^{\circ} \mathrm{C}$ and $500 \mathrm{~mm} / \mathrm{min}$. Another property used to evaluate elastomers deterioration was hardness, analyzed according to ASTM procedure D2240 [9].

For both models, vehicles that run on B5 and those that run on B20 had similar elongation and hardness results. But it's necessary to notice that the test field duration corresponds to a small part of the expected life for those materials and the absence of degradation cannot be extrapolated for longer periods of time. Further tests are 
required to determine the consequences of the use of blends with higher content of biodiesel.

6.3. Metallic parts of fuel systems - fuel coolers and filling tubes

In the Ford Transits, filling tubes were manufactured in austenitic stainless steel and showed no signs of wear or corrosion. The same was verified on fuel coolers, manufactured in aluminium.

The ford Rangers had no fuel coolers but the filling tubes, manufactured in carbon steel with organometallic coating, showed signs of corrosion only when exposed to B20, as can be observed in Figures 4 and 5.

Figure 4. Filling tube of a Ford Ranger that run on B5
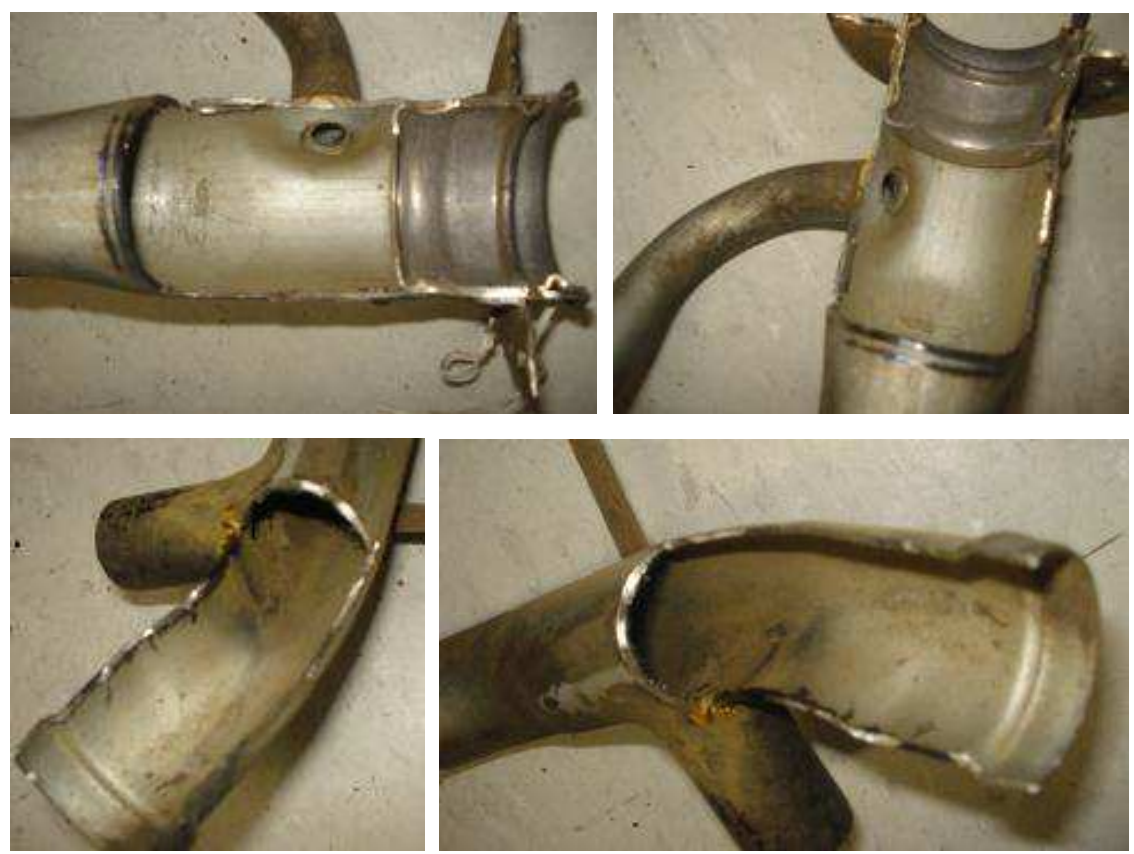

Figure 5. Filling tube of a Ford Ranger that run on B20
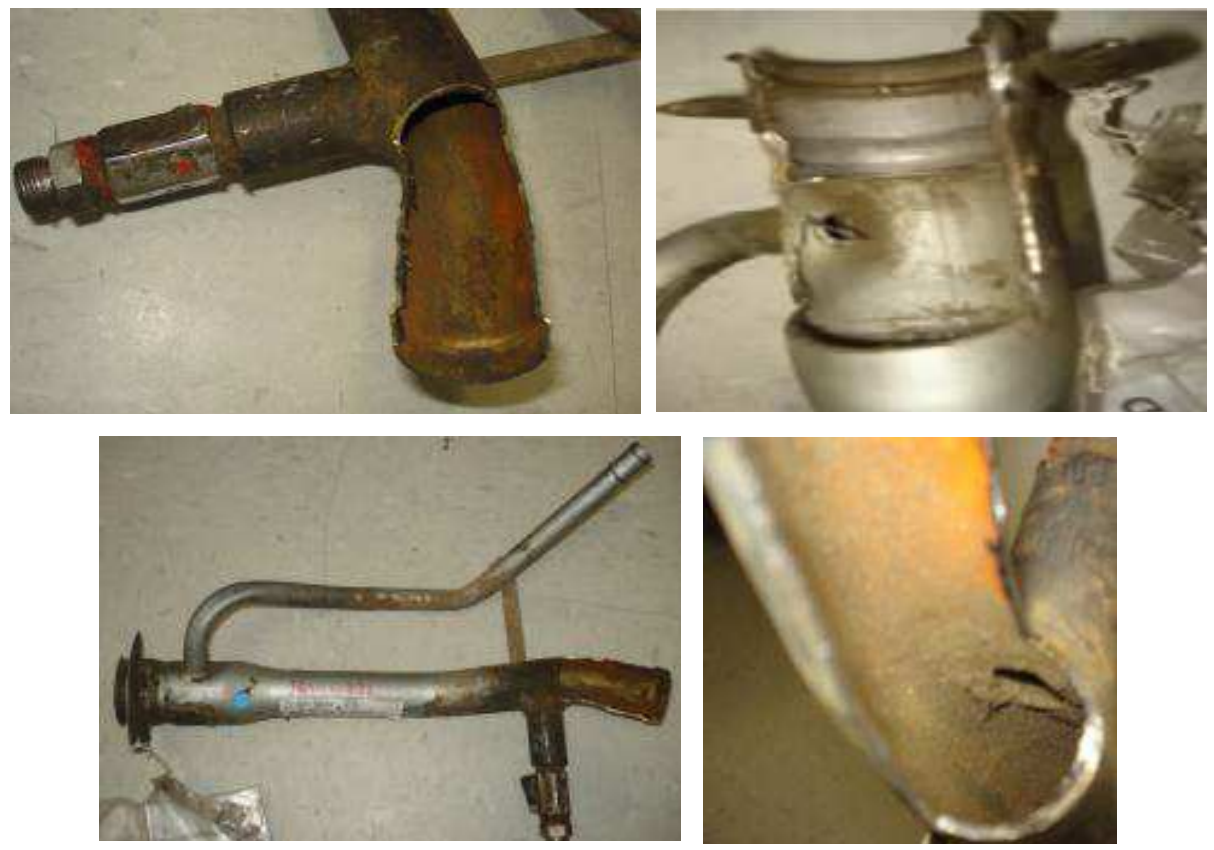
Again it's necessary to notice that the duration of the field test was significantly smaller than the expected life of those parts. In case of failure, as happened in the Ford Rangers, it is a clear sign of materials incompatibility. If no signs of wear or corrosion are detected, further tests are needed to evaluate the real extent of material durability when subjected to those fuels.

\section{CONCLUSION}

This work analyzes the impact of the use of a $20 \%$ biodiesel in diesel blend (B20) in light vehicles with EURO III and EURO IV technologies, concerning the durability of engines and systems. Vehicles running on B5 and B20 were submitted to similar field test conditions and accumulated $100.000 \mathrm{~km}$ during one year in urban and road circuits. They were then evaluated according to the deterioration of their performance and emissions, and the corrosion and wear of parts and components.

The Ford Transits, with EURO IV technology, were less sensible to the increase from $5 \%$ to $20 \%$ of the content of biodiesel in diesel. Those vehicles did not show significant differences between the two groups in none of the evaluated parameters.

The Ford Rangers, with EURO III technology, showed performance losses of $7 \%$ for those that run on B20 when compared to those that run on B5. An increase on wear on cylinders surfaces was also noted on B20, along with corrosion on metallic parts (manufactured in carbon steel with organometallic coating) of the filling system. All other parameters didn't show significant differences.

That difference in behavior between the two models indicates that older technologies are more susceptible to problems due to the increase of the contents of biodiesel in diesel. Newer technologies already count on more resistant materials and more intelligent combustion system controls, hence being more adaptable to differences in fuels.

It should be highlighted, however, that the duration of the field test corresponds only to part of the expected life of some materials and further researches must be made in order to evaluate the impacts of prolonged use of higher biodiesel content fuels.

\section{ACKNOWLEDGEMENTS}

This work is the result of a partnership between Petrobras and Universidade de Salvador UNIFACS. Other participants are Ford, MWM International, Mahle Metal Leve, BR Distribuidora, Continental, TI Automotive, IBTR (Instituto Brasileiro de Tecnologia e Regulamentação), SENAI-CIMATEC and Michelin.

\section{REFERENCES}

[1] BIODIESEL - HISTORICAL BACKGROUND. Available at WIKIPEDIA. http://en.wikipedia.org/wiki/Biodiesel. Accessed on 2012-04-25.

[2] BRASIL. Resolução ANP ñ 7, de 19.03.2008. Diário Oficial da República Federativa do Brasil, Brasília, DF, 20 de março de 2008.

[3] PROGRAMA NACIONAL DE PRODUÇÃO E USO DE BIODEISEL. Available at www.biodiesel.gov.br. Accessed on 2011.07.07. 
[4] BRASIL. Resolução CONAMA nº 418, de 25.11.2009. Diário Oficial da República Federativa do Brasil, Brasília, DF, 26 de novembro de 2009.

[5] SOCIETY OF AUTOMOTIVE ENGINEERS. Vehicle Acceleration Measurement. SAE Recommended Practice J1491. July 2006.

[6] ASSOCIAÇÃO BRASILEIRA DE NORMAS TÉCNICAS. Veículos rodoviários automotores leves - Determinação de hidrocarbonetos, monóxido de carbono, óxidos de nitrogênio, dióxido de carbono e material particulado no gás de escapamento. ABNT NBR 6601. 2005

[7] ASSOCIAÇÃO BRASILEIRA DE NORMAS TÉCNICAS. Veículos rodoviários automotores leves - Determinação de aldeídos e cetonas contidos no gás de escapamento, por cromatografia líquida - Método DNPH. ABNT NBR12026. 2009

[8] AMERICAN SOCIETY FOR TESTING AND MATERIALS. Standard Test Methods for Vulcanized Rubber and Thermoplastic Elastomers-Tension. ASTM D412 - 06a. 2013.

[9] AMERICAN SOCIETY FOR TESTING AND MATERIALS. Standard Test Method for Rubber Property-Durometer Hardness. ASTM D2240 - 05. 2010. 